\title{
Current Status of Quality Assurance Scheme in Selected Undergraduate Medical Colleges of Bangladesh
}

\author{
Dr. Shamima Rahman ${ }^{1}$, Dr. Mossammat. Nigar Sultana ${ }^{2}$, Dr. Pratima Rani Biswas ${ }^{3}$, Dr. \\ Mamata Manjari ${ }^{4}$, Dr. Rokhshana Khatun ${ }^{5}$
}

\begin{abstract}
This descriptive cross sectional study was carried out to determine the current status of Quality Assurance Scheme in undergraduate medical colleges of Bangladesh. This study was carried out in eight (four Government and four Non- Government) medical colleges in Bangladesh over a period from July 2015 to June 2016. The present study had an interview schedule with open question for college authority and another interview schedule with open question for head of department of medical college. Study revealed that $87.5 \%$ of college had Quality Assurance Scheme (QAS) in their college, 75\% of college authority had regular meeting of academic coordination committee in their college, $50 \%$ of college had active Medical Education Unit in their college, $87.5 \%$ of college authority said positively on publication of journal in their college. In the present study researchers interviewed 53 heads of department with open question about distribution, collection of personal review form, submission with recommendation to the academic co-coordinator, and annual review meeting of faculty development. The researchers revealed from the interviews that there is total absence of this practice which is directed in national guidelines and tools for Quality Assurance Scheme (QAS) for medical colleges of Bangladesh.
\end{abstract}

Keywords: Quality Assurance Scheme, Medical education, Current status.

1.Assistant Professor, Gynaecology \& Obstetrics, Colonel Malek Medical College, Manikgonj;

2.Assistant Professor, Gynaecology and Obstetrics, Mugda Medical College, Dhaka

3.Assistant Professor, Gynaecology \& Obstetrics, Colonel Malek Medical College, Manikgonj

4.Assistant Professor, Gynaecology \& Obstetrics, Colonel Malek Medical College, Manikgonj

5. Assistant Professor, Gynaecology \& Obstetrics, Colonel Malek Medical College, Manikgonj

Address of correspondence : Dr. Shamima Rahman Assistant Professor, Gynaecology \& Obstetrics, Colonel Malek Medical College, Manikgonj;

\section{Introduction}

Globalization of medicine is increasing, as manifested by the growing number of migrating doctors and cross-border education providers. In addition, new medical schools of dubious quality are proliferating. This situation accentuates the need to define standards and introduce Bangladesh Journal of Medical Education 2022; 13(1); Rahman et al., publisher and licensee Association for Medical Education. This is an Open Access article which permits unrestricted noncommercial use, provided the original work is properly cited. 
effective and transparent accreditation systems. The WHO/WFME Guidelines recommend establishing accreditation that is effective, independent, transparent, and based on criteria specific to medical education. Promotion of national accreditation systems will pivotally influence future international appraisal of medical education ${ }^{1}$.

Quality Assurance (QA) being the guarantee that the required standard being met is one of the means of maintaining or improving standards of medical education and consequently health care delivery. Quality Assurance involves of teaching/learning and assessment methods being practiced at the medical institutes. Medical institutes have to demonstrated Quality Assurance in order to guarantee their products are competent enough and as per curricular objectives ${ }^{2}$.

Quality assurance is a continuous process which involves measurement, judgment and steps taken for improvement in the process so that the final product meets the specifications of quality. This systematic, structured and continuous improvement helps in ensuring that the product is always relevant to the current demands. Quality assurance can be managed through an institutional monitoring that should include the course evaluation, peer evaluation and the assessment. Accreditation is a process, widely used in higher education to evaluate the quality educational programs. Quality can be assured by transparent selection procedures, well-established entrance examinations, centrally regulated curricula, self-evaluation and academic audits conducted by the institutions themselves, appointing external examiners and requirement of national examinations before licensure ${ }^{3}$.

Quality of health care is influenced by several factors, but perhaps the most fundamental is the education and training of the doctors who delivers that health care. Quality assurance (QA) in medical education is one of the means of maintaining or improving standards of health care delivery. Those who have responsibilities for the delivery of health care and those who have responsibility for training to deliver health care, therefore, have a common purpose, and should be working in partnership to achieve their goal. All medical colleges in Bangladesh recognized that in educating the doctors of the future, they have responsibilities, not only to fund providers, employers of medical graduates and licensing authorities but ultimately to the society ${ }^{3}$.

Quality Assurance in medical education is the safe guard of the curricular objectives designed to produce competent graduates. These competent medical graduates are capable to deliver optimum health care services upholding world standards and the demand of the community. To achieve this level requires co-ordinate activities of the

Bangladesh Journal of Medical Education 2022; 13(1); Rahman et al., publisher and licensee Association for Medical Education. This is an Open Access article which permits unrestricted noncommercial use, provided the original work is properly cited. 
institutes concerned and monitoring agencies like BM\&DC, MOH\&FW, DGHS, CME and Deans' offices ${ }^{2}$.

In Bangladesh, standards of the medical education and practices of all the undergraduate institutes are supervised and regulated by the Bangladesh Medical and Dental council (BM\&DC), Centre for Medical Education (CME) is acting as secretariat of QAS in collaboration with Director of Medical Education of Director General of Health Services (DGHS) ,Bangladesh Medical and Dental Council (BM\&DC), Ministry of Health and Family Welfare(MOHFW)Universities, World Health Organization (WHO) and Association for Medical Education(AME), Bangladesh are working together to develop and maintain quality medical education in the country ${ }^{4}$.

In consideration of above mentioned facts, the researcher in this study had tried to find out the current status of Quality Assurance Scheme (QAS) in different medical colleges in Bangladesh; its strength \& weakness. Findings of the study may suggest some modifications and strengthening of present programme.

\section{Methodology}

This was a descriptive type of crosssectional study, carried out from July 2015 to June 2016 to assess the current status of practice of Quality Assurance Scheme
(QAS). This study was conducted in the eight medical colleges of Bangladesh, four governments (two from Dhaka city, two outside Dhaka city) and four nongovernment institutes (two from Dhaka city two outside Dhaka city). The study population of this study were college authority (Principal, vice Principal, Academic Coordinator, Chairperson), Head of department of different disciplines of the selected medical colleges.

The head of departments were enrolled from eleven major departments of eight medical colleges as per under graduate medical curriculum. Sampling was done by convenience sampling. During development of questionnaire personal review form of faculty development \& review scheme which is the part of National Guidelines\& Tools for Quality Assurance Scheme (QAS) for Medical Colleges in Bangladesh were studied. Other studies related to faculty development were studied. The questionnaire developed in an improvised manner. Data collection instrument were

1. An interview schedule with open question for college authority

Bangladesh Journal of Medical Education 2022; 13(1); Rahman et al., publisher and licensee Association for Medical Education. This is an Open Access article which permits unrestricted noncommercial use, provided the original work is properly cited. 
2. An interview schedule with open question for head of department of medical colleges

The data collection instruments were pretested upon college authority and the six head of the department of Dhaka Medical College. The Principals of the medical colleges were approached through a forwarding letters from director $\mathrm{CME}$ describing the purpose of the study \&requested necessary permission to conduct the study. The researchers had visited the selected medical college personally. They introduced themselves to the concerned authority of the medical college's hospital and were seeking permission to conduct the study. After permission from college authority interview was conducted with open question. Some information supplemented from Annual Report on Quality Assurance Scheme (QAS) of a Medical College. After permission from head of the department interviews were conducted with open question.

Open question were edited after collection and coded manually. Qualitative part of data checked\& edited after collection. Then responses were listed according to theme, frequency were tally marked. Tallies added and data presented in the form of tables. Necessary description had given to show the findings. Participation by the respondent in the study was totally voluntary. Anonymity of the respondents was maintained. Confidentiality of the information was ensured. Name of college and teacher was not disclosed. Findings of the study were used only for research purpose.

\section{Results}

Results of this study organized by different tables.

Table 1. Distribution of college authority by their opinion about Quality Assurance Scheme (QAS) present in their college $(\mathrm{n}=8)$

\begin{tabular}{|l|c|c|}
\hline \multicolumn{1}{|c|}{$\begin{array}{c}\text { Quality Assurance } \\
\text { Scheme(QAS) }\end{array}$} & Frequency & Percent \\
\hline Present & 7 & 87.5 \\
\hline Absent & 1 & 12.5 \\
\hline Total & 8 & 100.0 \\
\hline
\end{tabular}

Table 1 showed that $87.5 \%$ of college authority said presence of Quality Assurance Scheme (QAS) in their college

Bangladesh Journal of Medical Education 2022; 13(1); Rahman et al., publisher and licensee Association for Medical Education. This is an Open Access article which permits unrestricted noncommercial use, provided the original work is properly cited. 
Table 2.Distribution of college authority by conduction of meeting of academic coordination committee meeting in their college $(n=8)$

\begin{tabular}{|l|c|c|}
\hline $\begin{array}{l}\text { Meeting with academic } \\
\text { coordinator }\end{array}$ & Frequency & Percent \\
\hline Regular & 6 & 85.0 \\
\hline Irregular & 1 & 12.5 \\
\hline Not conducted at all & 1 & 12.5 \\
\hline Total & 8 & 100 \\
\hline
\end{tabular}

Table 2 showed that $75 \%$ of college authority said regular meeting of academic coordination committee occurred in their college

Table 3. Distribution of college authority by Faculty development programme present in their college $(n=8)$

\begin{tabular}{|l|c|c|}
\hline $\begin{array}{c}\text { Faculty development } \\
\text { programme }\end{array}$ & Frequency & Percent \\
\hline Present & 7 & 87.5 \\
\hline Absent & 1 & 12.5 \\
\hline Total & 8 & 100.0 \\
\hline
\end{tabular}

Table 3 showed that $87.5 \%$ of college authority said presence of Faculty development programme in their college.

Table 4. Distribution of college authority by Medical Education Unit present in their college $(\mathrm{n}=8)$

\begin{tabular}{|l|c|c|}
\hline \multicolumn{1}{|c|}{ Medical Education Unit } & Frequency & Percent \\
\hline Active & 4 & 50 \\
\hline Not active & 3 & 37.5 \\
\hline Absent & 1 & 12.5 \\
\hline Total & 8 & 100 \\
\hline
\end{tabular}

Table 4 showed $50 \%$ of college authority said active Medical Education Unit in their college.

Table 5. Distribution of college authority by publication of journal in their college $(n=8)$

\begin{tabular}{|l|c|c|}
\hline \multicolumn{1}{|c|}{ Publication of journal } & Frequency & Percent \\
\hline Yes & 7 & 87.5 \\
\hline No & 1 & 12.5 \\
\hline Total & 8 & 100.0 \\
\hline
\end{tabular}

Table 5 showed $87.5 \%$ of college authority said positively on publication of journal in their college

Bangladesh Journal of Medical Education 2022; 13(1); Rahman et al., publisher and licensee Association for Medical Education. This is an Open Access article which permits unrestricted noncommercial use, provided the original work is properly cited. 
In the present study researchers interviewed

53 heads of department with open question about distribution, collection of personal review form, submission with recommendation to the academic coordinator, and annual review meeting of faculty development. The researchers observed from the interviews that there was total absence of this practice which is directed in national guidelines and tools for Quality Assurance Scheme (QAS) for medical colleges of Bangladesh.

\section{Discussion}

Most of the institute (87.5\%) which included in the present study had Quality Assurance scheme(QAS) in their college. Halder showed that $80.8 \%$ medical colleges had the committee of Quality Assurance Scheme (QAS) like academic council ${ }^{5}$. A cross sectional study conducted by Talukder et al to assess regarding the assurance scheme (QAS) at different medical and dental colleges in Bangladesh it was found that QAS is fully functioning in $46.5 \%$ colleges, partially functioning $45.9 \%$ colleges, non-functioning in $3.9 \%$, absent in $3.6 \%$ colleges $^{4}$.

In the present study majority (75\%) of the college authority selected for study stated that regular meeting, $12.5 \%$ college authority stated that irregular conduction of meeting of academic coordination committee occurred in the colleges. Halder stated that $68.1 \%$ medical colleges had complete operational framework for $\mathrm{QAS}^{5}$. Most of the institute $(87.5 \%)$ selected for the present study had faculty development programme (Table 3). Halder showed that $61.5 \%$ medical college had faculty development and review committee and $76.9 \%$ had faculty development programme ${ }^{5}$ A cross sectional study conducted by Talukder reported that $82 \%$ medical colleges had faculty development and review scheme of operational framework of QAS. Both studies had similar findings of the present study ${ }^{4}$.

In the present study half (50\%) of college authority stated that presence of active Medical Education Unit in their college. Cross sectional study conducted by Rahman stated that $96.2 \%$ (101 out of 105) medical colleges are having MEU during data collection ${ }^{7}$. Most $(87.5 \%)$ of the institute selected for present study stated that they had published their journal regularly.

In the present study, from the interview of 53 head of the department found that total $(100 \%)$ absence of distribution, collection

Bangladesh Journal of Medical Education 2022; 13(1); Rahman et al., publisher and licensee Association for Medical Education. This is an Open Access article which permits unrestricted noncommercial use, provided the original work is properly cited. 
of personal review form, submission with recommendation to the academic coordinator and annual review meeting of faculty development. Halder showed in his study $76.9 \%$ medical colleges never asked their faculty to fill up the personal review form or hold annual review meeting for faculty development ${ }^{5}$.

\section{Conclusion}

National guidelines and tools for Quality Assurance Scheme (QAS) for medical colleges in Bangladesh serve as an instrument for attaining global standard. This study observed that $t$ many lacking present in current practice of QAS in medical institutes. There were lacks of awareness of college administration for improvement of quality assurance activities. Although small number of colleges had some of quality assurance activities, but in majority of the colleges which included in the present study QAS activities not up to the mark.

\section{References}

1.Karle H. Global standards and accreditation in medical education: a view from the WFME. Acad Med. 2006 Dec;81(12 Suppl):S43-8. doi: 10.1097/01.ACM.0000243383.71047.c4.

PMID: 17086046.
2., National Education Guidelines and Tools for Quality Assurance Scheme.(QAS) for Medical Colleges in Bangladesh.2012;CME \& DGHS, supported by World Health Organization

3. IMI Institute of Medical Illustrator UK. Http/www.google.com Last updated: 07 September 2009 at 09:20.

4. Talukder MHK, Nazneen R, Hossain MZ, Nargis T, Alam KK, Chowdhury IJ \&Parveen I, Quality Assurance Scheme (QAS) in Medical \& Dental Colleges in Bangladesh-Teachers knowledge, Bangladesh Journal of Biochemistry.2013; 3(1): 6-10.

5. Halder BB, Current practice of Quality Assurance Scheme (QAS) in different medical colleges of Bangladesh, Bangladesh Medical Journal of Education. 2015;6(1): 27.

6. Raihan Md. M, Afroza A, Talukder MHK, Harun AA,Quality assurance in undergraduate dental institutions of Bangladesh: Views of stakeholders, Bangladesh Medical Journal of Education. 2017;8(2): 7-11.

7. Rahaman S, Talukder MHK, Alam KK, Activities of Medical Education Unit (MEU) in Medical Colleges of Bangladesh and some challenges faced, Bangladesh Medical Journal of Education. 2019;10(2): 12-18.

Bangladesh Journal of Medical Education 2022; 13(1); Rahman et al., publisher and licensee Association for Medical Education. This is an Open Access article which permits unrestricted noncommercial use, provided the original work is properly cited. 

commercial use, provided the original work is properly cited. 